\title{
Editorial
}

\section{MARCANDO PRESENCIA!}

What does it mean to be invisible in a society in which visibility - the need to marcar presencia - is the essential marker of belonging? Why have South Americans been neglected in the literature on Latino/as for so long? And why do they also seemed to have chosen to remain aloof from other Latino/as? How are South Americans positioned in the struggle to find unifying threads among Latino/as? How do they contribute or not to Latinismo? Where do Brazilians fit into the discussion?

A few months ago, these and other similar questions led us to organize a conference titled Los que llegaron: South Americans Immigrants in the United States, in an effort to contribute to what seems to be a much-needed process to document the experience of this still largely unknown, yet growing, population. The articles in this special feature were among several presented at that conference. They reflect both the complex heterogeneity of the South American population and the need to document its experience in relation to the more traditionally studied Latino groups. Bernadete Beserra, for example, provides us with a nuanced discussion of how Brazilians negotiate their Brazilianness and Latinidad in their process of integrating into US society. She examines some of the problems at stake in Brazilians' negotiation of identity and space in Los Angeles, and argues that in the racialized and racializing context of US society, all Brazilians have to go through a profound questioning of their racial identities because of their transformation into Latinos. Hence, she suggests, it is not enough for Brazilians to insist on their national identities as Brazilians.

Language and nationality are almost self-evident issues in defining latinidad in the US context. Yet the question of class is an equally important, albeit more subtle, obstacle to the construction of latinismo. As Elena Sabogal's essay pointedly reminds us, our notions of class include often-misleading perceptions about arriving immigrants. Her essay focuses on the experiences of middleclass Peruvian professionals who have recently migrated to the United States. Sabogal's research shows that many arrive without legal status, language skills or employment sponsorship. Without these resources, they experience employment instability, downward mobility and greater emotional stress.

While Sabogal focuses on middle-class urban professionals from Peru, Karsten Paerregaard's article explores the construction of the Peruvian diaspora in a different way. Focusing on several cities of the United States, he examines the ways that Andean folklore has become an issue of contestation and conflict between Peruvians from the urban middle class and the rural working class, in their efforts to forge immigrant identities and generate new forms of income in this country.

. Latino Studies 2005, 3, (1-2) (c) 2005 Palgrave Macmillan Ltd 1476-3435/05 \$30.00

www.palgrave-journals.com/lst 
Macarena Gómez-Barris examines the changing nature of Latinismo through the experiences of the growing second generation of South American immigrants. Her article analyzes "Two 9/11s in a Lifetime," a San Francisco project and art exhibit on the politics of memory that addressed the simultaneous experience of living through the Chilean military coup on September 11, 1973, and the New York attack on the Twin Towers on September 11, 2001. Her aim is to illuminate the complex relationship of USbased Chilean exiles and their Latino/a sons and daughters, to historical memory, displacement, and political engagement. My introduction to this special feature on South Americans aims to provide an overview to contextualize the various waves of South Americans in the United States since the second half of the 20th century.

South American nationals, of course, are not the only groups whose presence has begun to be documented among Latino/as in the United States. Ana Patricia Rodríguez's article focuses on the ambivalence of Salvadorans' narratives about their migration experience. She points to the migrants' critique of the mythology of "el hermano lejano," noting the extent to which their roles as transnational actors is valued and used by the Salvadoran state.

The diversity and complexity of these "new" "other Latino/as" increasingly complicate the construction of latinismo in the US context. Nevertheless, efforts to identify latinidad and to forge latinismo continue to be seen in different ways throughout US society. Raphael Dalleo's article is an attempt to build bridges between apparently discreet Hispanic-American traditions and to affirm a Latina Literary tradition. Analyzing Cristina Garcia's novel in its relation to particular tropes from The House on Mango Street, he shows Dreaming in Cuba to be an "inheritor of hybrid versions of Latin American, Caribbean, and North American cultures." He argues that Garcia's novel paints a portrait of Latina experience and of the Latina novel as "pan-ethnic."

Latino/as are today increasingly marcando presencia in different venues, and in different ways - one of the most powerful being the 2003 freedom rides, described by Alejandro Luis Molina and Michael Reyes in their photo essay and poem. As their work suggests, the ongoing struggle to belong, like the affirmation of the right to have rights, is necessarily a collective process. To affirm our individual presence - to insist on its visibility - is also to affirm our collective human dignity.

Saludos!

Suzanne Oboler University of Illinois at Chicago

Latino Studies (2005) 3, 1-2. doi:10.1057/palgrave.lst.8600132 